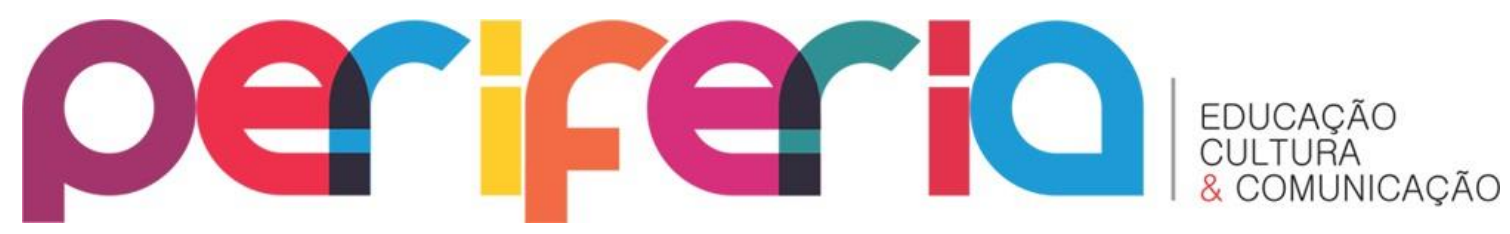

\title{
O QUE CONTAM OS SAMBISTAS DE MADUREIRA E OSWALDO CRUZ SOBRE AS RODAS DE SAMBA NOS QUINTAIS DA PERIFERIA SUBURBANA
}

\author{
Cristina da Conceição Silva ${ }^{1}$ \\ Universidade Candido Mendes \\ Faculdade de Educação da Baixada Fluminense - FEBF/UERJ \\ Secretaria Municipal de Nova Iguaçu
}

\section{RESUMO}

O presente artigo visa abordar as contribuições culturais do negro na cidade do Rio de Janeiro, a partir dos encontros festivos, acompanhados de comidas e rodas de samba, nos quintais suburbanos de Madureira e Oswaldo Cruz. Para o seu desenvolvimento, abordaremos fatos que envolvem o advento da Reforma Urbana da cidade carioca, que teve início em 1903, com o Prefeito Pereira Passos, incentivada pelo presidente Rodrigues Alves. O presidente levantou os recursos e o prefeito pôde realizar as obras e a higienização da cidade ficou nas mãos do médico Oswaldo Cruz, diretor do Serviço de Saúde Pública. A reforma urbana carioca foi inspirada na reforma feita em Paris no século XIX, entre 1853 e 1870, e ficou conhecida como Bota-Abaixo. Em sua gestão, Passos modernizou a Zona Portuária, criou a Avenida Central (hoje Rio Branco) a Avenida Beira-Mar e a Avenida Maracanã. Esse episódio provocou o deslocamento dos negros que viviam no centro da cidade, pela malha ferroviária, para a geografia suburbana. Esses grupos étnicos, frente à ausência de políticas de entretenimento na geografia suburbana, fazem de seus quintais um espaço de convivência, onde o ritmo do samba, iguarias e encontros entre amigos funcionam como elementos de socialização. Para o desenvolvimento deste artigo foram utilizadas bibliografias acerca da temática e das narrativas dos sambistas moradores dos bairros de Madureira e Oswaldo Cruz.

Palavras-chave: Samba, quintais, subúrbio, periferia.

\section{WHAT SAMBISTAS FROM MADUREIRA AND OSWALDO CRUZ COUNT ABOUT THE SAMBA CIRCLES IN THE BACKYARDS OF SUBURBAN PERIPHERY ABSTRACT}

This article aims to address the cultural contributions of black in the city of Rio de Janeiro, from the festive gatherings, accompanied by food and samba, in suburban backyards of Madureira and Oswaldo Cruz. For the development of it, discusses facts surrounding the arrival of Urban Reform Carioca city, which started in 1903, by mayor Pereira Passos, encouraged by President Rodrigues Alves. The president managed to the resources and the mayor could do the works and sanitation of the city was the responsibility of the doctor Oswaldo Cruz, director of the Public Health Service. The

\footnotetext{
${ }^{1}$ Mestre em Educação pela Universidade do Grande Rio Professor José de Souza Herdy (Unigranrio). E-mail: cristinavento24@yahoo.com.br
} 


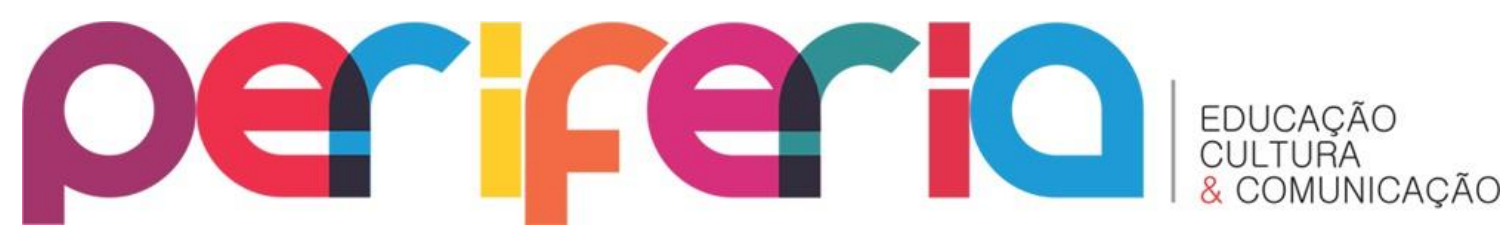

carioca urban reform was inspired by the reform made in Paris in the nineteenth century, between 1853 and 1870, and became known as Bota-Abaixo. During his tenure, steps modernized the Port Zone, created Central Avenue, now Rio Branco, Beira-Mar Avenue and Maracanã Avenue. This episode caused the displacement of blacks who lived in the city center via the railway to suburban geography. These opposite the absence of political entertainment in suburban geography, ethnic groups make their backyard a space of living together, where the rhythm of samba, delicacies and gatherings among friends function as elements of socialization. Therefore, the development of this article bibliographies were utilized concerning the theme and narrative of samba residents of neighborhoods Madureira and Oswaldo Cruz.

Keywords: Samba, backyards, suburban, periphery.

\section{INTRODUÇÃO}

A investigação em pauta apresenta minhas narrativas em virtude de uma vivência com o universo do samba e seus atores, especialmente com os pertencentes à velha guarda da Escola de Samba Portela. Quanto às minhas atividades profissionais, sou professora do curso de Pedagogia da Universidade Cândido Mendes - campus Araruama; professora substituta no curso de Formação de Professores na Faculdade de Educação da Baixada Fluminense, da Universidade do Estado do Rio de Janeiro (UERJ); e professora de História do Ensino Básico na Prefeitura Municipal de Nova Iguaçu.

$\mathrm{Na}$ graduação, tenho formação em Pedagogia e História pela Sociedade Universitária Augusto Mota; sou especialista em Diversidade Étnica em Educação pela Universidade Federal Rural do Rio de Janeiro - campus Nova Iguaçu; e mestre em Letras e Ciências Humanas (linha Gênero, Etnia e Identidade) pela Universidade do Grande Rio Professor José de Souza Herdy (Unigranrio).

Esse artigo visa apresentar o advento do samba na cidade do Rio de Janeiro, a partir das diversas práticas culturais exercidas pelos grupos étnicos vindos do continente africano para a cidade carioca. Esses grupos, ao longo do tempo, constituíram aspectos socializadores nos encontros festivos promovidos em espaços privados na periferia do subúrbio carioca.

Um dos lugares onde ocorreram esses aspectos socializadores foram os quintais do sertão carioca de Madureira. Segundo Vargens e Monte (2001), este era 


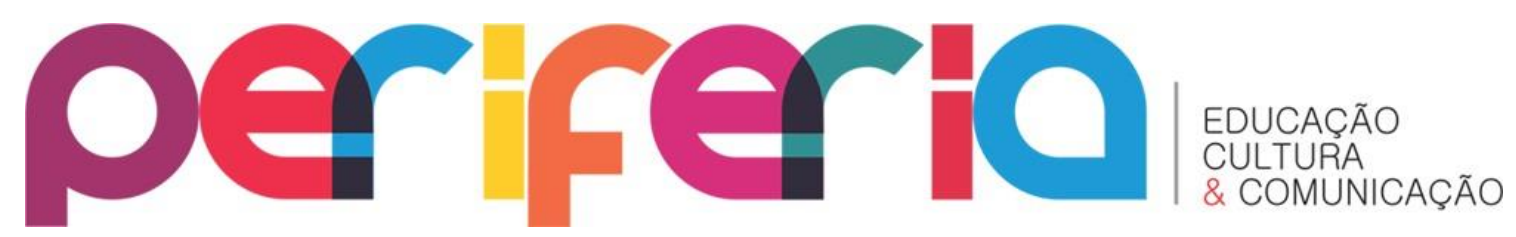

um bairro que, na virada do século XIX para o século $X X$, já tinha se tornado importante eixo ferroviário com a inauguração das estações de Madureira (1890), na antiga Estrada de Ferro Dom Pedro II, e de Inharajá (1908) - atual estação Mercado de Madureira ou Magno, na antiga Estrada de Ferro Melhoramentos do Brasil (Linha Auxiliar). Em 1958, com a inauguração do Viaduto Negrão de Lima, foram interligadas as áreas do bairro separado pelos ramais da linha férrea.

Outro bairro em que também aconteciam encontros festivos promovendo a socialização foi Oswaldo Cruz. Para Vargens e Monte (2001), esse bairro cresceu ao longo das ruas João Vicente e Carolina Machado, que foram reconhecidas como logradouros em 1917; tinham casario simples, comércio local modesto e vielas. Até a década de 1960, o trem e o lotação eram o principal meio de transporte da população local. Na década de 1970, surgiram os conjuntos habitacionais: o conjunto Oswaldo Cruz (conhecido como Cohab) e o conjunto Nelson Pereira dos Santos.

Diante deste contexto, abordaremos a história do samba nos bairros suburbanos, nas práticas de entretenimento desenvolvidas pelos negros após a Reforma Urbana promovida por Pereira Passos. Tal Reforma ocorreu nos primórdios do século XX no Centro do Rio de Janeiro, esse advento levou muitos negros a seguirem a malha ferroviária para os bairros suburbanos em busca de moradia. Para desenvolver este artigo, descrevo a minha relação com a cultura do subúrbio, onde nasci e moro até os dias atuais, e que me impulsionou desde muito pequena a desenvolver gosto pelo samba e pelo carnaval. No final da década de 1970, por volta dos meus quinze anos, junto com minhas irmãs mais velhas, visitava as quadras da Escola de Samba Império Serrano, que, segundo Araújo (2000), foi fundada em 1947 no Morro da Serrinha, e da Escola de Samba Portela, que, de acordo com o mesmo autor, foi fundada em 1923, no bairro de Oswaldo Cruz, a partir da união dos blocos Baianinhas de Oswaldo Cruz e Quem Fala de Nós Come Mosca, depois Quem Faz é o Capricho e Vai Como Pode; por fim, em 1935, se tornou o Grêmio Recreativo Escola de Samba Portela. Conforme esse autor, em 1970, a Escola de Samba Portela passou a ter sua quadra localizada na Rua Clara Nunes, em Madureira. 


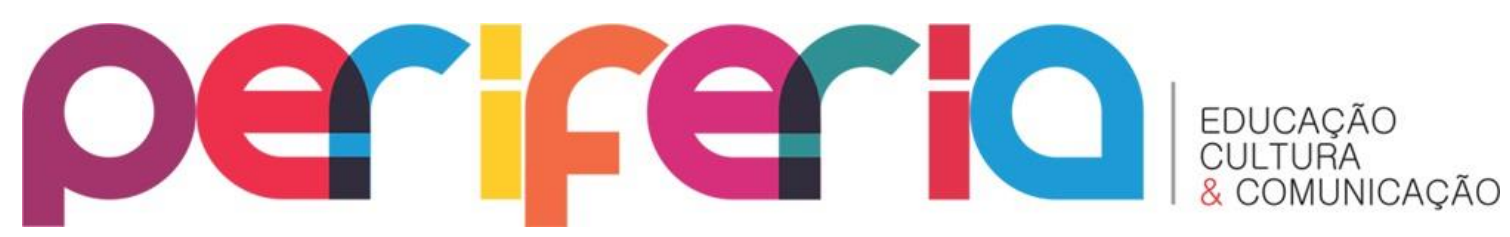

Com o passar dos anos, minha presença se fazia constante nos ensaios da Escola de Samba Portela. Foi a partir desses eventos que conheci integrantes da Velha Guarda e demais sambistas. No decorrer dos anos, suas narrativas enriqueceram meus conhecimentos acerca dos eventos festivos que envolviam a história dos bairros de Madureira e Oswaldo Cruz.

A minha convivência com a Velha Guarda da Portela em seus shows, nos ensaios e nas festas promovidas em seus quintais nos bairros de Madureira e Oswaldo Cruz me forneceram conhecimento acerca da cultura afro carioca no que se refere à cultura do samba no subúrbio carioca.

Ao consultar manuais que me indicassem um modelo de pesquisa, deparei com dificuldades para encontrar metodologias que recomendassem um modelo de regras de aproximação e escuta na ocasião de uma pesquisa de campo em que o pesquisador se apresente intimamente envolvido. Logo, utilizei pesquisa qualitativa com base em materiais bibliográficos e coleta de dados, por meio de entrevistas com os integrantes da Velha Guarda da Portela.

Ribeiro (2008) aponta como vantagens da utilização da técnica da entrevista a flexibilidade na aplicação, a facilidade de adaptação de protocolo, a viabilização da comprovação e esclarecimento de respostas, a taxa de resposta elevada e o fato de poder ser aplicada em pesquisas. Para a autora, entrevista tornou-se, nos últimos anos, um instrumento do qual se servem constantemente, e com maior profundidade, os pesquisadores das áreas das ciências sociais e psicológicas. Recorrem estes à entrevista sempre que têm necessidade de obter dados que não podem ser encontrados em registros e fontes documentais, podendo ser fornecidos por determinadas pessoas.

Nesse sentido, mesmo tendo amplo conhecimento acerca da cultura do samba nos bairros de Madureira e Oswaldo Cruz, devido à minha vivência, senti necessidade de buscar compreender melhor a dinâmica do samba no Rio de Janeiro. Essa inquietação me levou a buscar junto aos sambistas - em especial os pertencentes à Escola de Samba Portela - dados que me levassem a compreender as contribuições do 


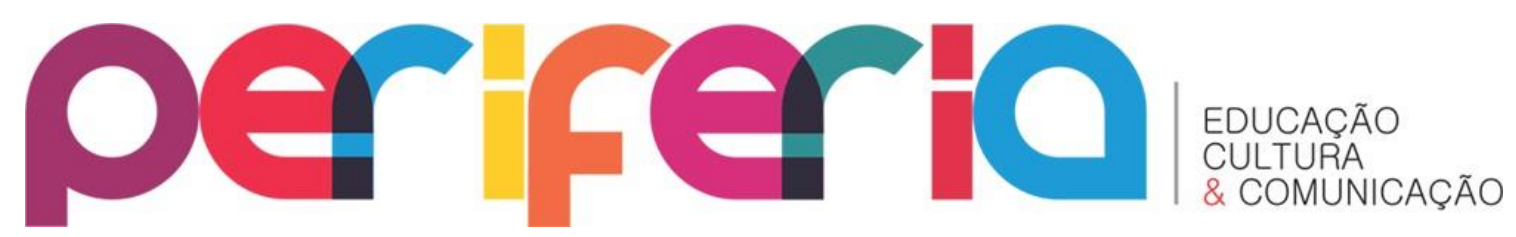

samba na cultura carioca; tais fatores garantiram minhas pesquisas de especialização e de mestrado.

A conversa com os sambistas mostrou como a cultura afro carioca se desenvolveu nos bairros de Madureira e Oswaldo Cruz e ganhou notoriedade no cenário brasileiro. A oralidade desses sambistas afrodescendentes permitiu observar a contribuição cultural e um modelo de civilidade implantado por eles no cenário carioca.

\author{
Eu sou o samba o samba \\ A voz do morro sou eu mesmo, sim, senhor \\ Quero mostrar ao mundo que tenho valor \\ Eu sou o rei do terreiro \\ Eu sou o samba \\ Sou natural daqui do Rio de Janeiro \\ Sou eu quem levo a alegria \\ Para milhões de corações brasileiros \\ Salve o samba, queremos samba \\ Quem está pedindo é a voz do povo de um país \\ Salve o samba, queremos samba \\ Essa melodia de um Brasil feliz (ZÉ KETI, 1955).
}

\title{
E O SAMBA PEDE PASSAGEM NO UNIVERSO DAS EXPRESSÕES CULTURAIS
}

A história do samba carioca apresenta, ao longo de sua existência, um modelo de representação de expressão cultural de grupos étnicos que vieram do continente africano para a cidade com seus ritmos e danças. Tais representações culturais existentes na cidade do Rio de Janeiro, ao se incorporarem, ao longo dos séculos, às expressões de grupos variados, deram origem à cultura afro-carioca, em especial o samba.

No começo do século XX, comunidades negras do Rio de Janeiro "rejeitadas de participação integral nos processos produtivos e políticos formais, caçadas e impedidas de comemorar abertamente suas folias e sua fé", deram forma a um novo samba, diferente dos tipos então conhecidos, que viria a ser chamado de samba urbano, samba carioca, samba de morro ou simplesmente samba. Elas também criaram as escolas de samba, espaços de reunião, troca de conhecimentos, estabelecimento de redes de solidariedade, criação artística e festa (THEODORO et alii, 2006). 


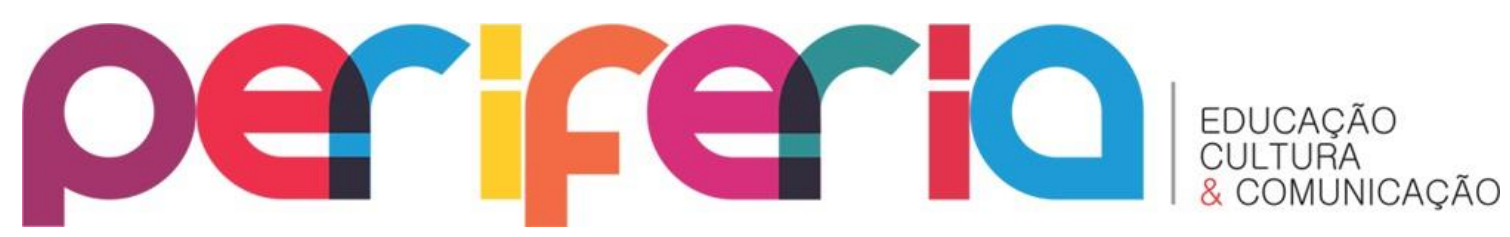

Ainda de acordo com os autores, no cenário brasileiro há artes musicais identificadas pelo termo, como o samba de roda do Recôncavo e o samba rural paulista. No entanto, o samba do Rio de Janeiro se destaca por ser um acontecimento cultural forte. Atravessou o século $X X$, passando de alvo de discriminação e perseguição nas primeiras décadas a ritmo coligado com a própria nação, a ponto de ser um de seus símbolos.

Atualmente, o samba é celebrado como a música popular do Brasil por excelência. Ele ocorre em todo o país em inúmeros gêneros e subgêneros e em amostras musicais de dança e de festejos da vida ocasionadas pelo que foi difundido ao longo dos séculos pelas populações africanas e afrodescendentes que aqui viveram e vivem.

O povo brasileiro, no que se refere ao universo das manifestações artísticas, expressa pela música um modelo evolutivo, sofisticado e original, apresentando riqueza melódica e inúmeras possibilidades rítmicas. Nos quesitos harmonia e inventividade, os compositores e instrumentistas brasileiros fazem da nossa produção musical um produto cultural de exportação respeitado e admirado em todo o mundo. E o samba é a origem, a raiz, a tradição. É a essência que conta, pelo canto e pelo ritmo, o cotidiano de homem comum dos que fizeram a história de nosso território nacional, conforme Theodoro et alii (2006).

\author{
O meu lugar \\ É caminho de Ogum e lansã \\ Lá tem samba até de manhã \\ Uma ginga em cada andar. \\ $O$ meu lugar \\ É cercado de luta e suor \\ Esperança de um mundo melhor \\ E cerveja pra comemorar... \\ $\mathrm{O}$ meu lugar \\ Tem seus mitos e seres de luz \\ É bem perto de Oswaldo Cruz \\ Cascadura, Vaz Lobo, Irajá. \\ $O$ meu lugar \\ É sorriso, é paz e prazer \\ O seu nome é doce dizer
}




\section{periferio}

Madureira, lá, laia...

Madureira, lá, laiá...

Ai meu lugar,

Quem não viu Tia Eulália dançar

Vó Maria o terreiro benzer

E ainda tem jongo à luz do luar...

Em cada esquina um pagode um bar,

Em Madureira.

Império e Portela também são de lá,

Em Madureira... (ARLINDO CRUZ; MAURO DINIZ).

\section{SEGUINDO PARA O SERTÃO CARIOCA}

O Rio de Janeiro, com suas medidas de saneamento e urbanização da capital da República nos primórdios do século XX, aliadas a outros fatores históricos e sociais, leva as populações mais pobres - dentre negros, estrangeiros e brancos empobrecidos - para o sertão carioca. Em virtude do advento republicano, surgem moradias nas encostas e contraencostas dos espaços que envolvem a Zona Norte da cidade carioca. Assim, vão nascendo núcleos residenciais e comerciais nessa geografia. As margens da malha ferroviária, um meio de transporte de massa, auxiliaram essa expansão e o sistema de moradia para outros espaços da cidade, antes e após a Reforma Urbana do Centro da cidade, segundo Rocha (1995).

Nesse contexto é que surgem os bairros da periferia suburbana e as relações étnico-raciais, pelas culturas de matrizes africanas, especificamente nos bairros de Madureira e Oswaldo Cruz, cujos novos moradores, que vieram das fazendas de café do Vale do Paraíba e do Centro da cidade, via malha ferroviária, estavam em busca de um espaço para viver com dignidade. Nesse sertão carioca, cercado de campos vastos e amplos terrenos, a população fixou suas residências.

$\mathrm{Na}$ falta de entretenimento público especificamente em Madureira e Oswaldo Cruz, os moradores passam a promover encontros festivos nos grandes quintais onde que residiam e assim minimizavam a ausência de políticas públicas, importantes para a dignidade humana. Os encontros festivos nos quintais dos novos moradores culminaram inicialmente em blocos carnavalescos, que, tempos depois, receberam a 


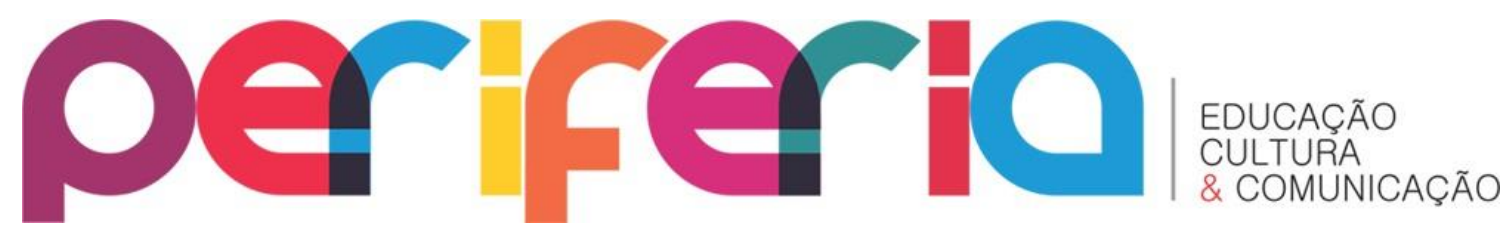

denominação de escolas de samba. Tais eventos promoveram encontros entre músicos e compositores já consagrados no mundo do samba e revelaram novos talentos no samba carioca.

\section{DE CONVERSA EM CONVERSA}

Durante os anos de relacionamento com os sambistas afro-cariocas e dirigentes da Escola de Samba Portela, conversamos muito sobre os eventos dos seus quintais, de amigos e da quadra da Portela, bem como suas participações nessas iniciativas no passado ou presente.

Embora minha participação em tais eventos em alguns casos se fizesse presente como convidada ou colaboradora, foi necessário sistematizar as narrativas dos sambistas de Madureira e Oswaldo Cruz nesta investigação. Passo então a transcrever as narrativas de Dona Neném, Zilmar Mendonça, Davi do Pandeiro, Tia Surica e Irani. Essas pessoas foram escolhidas por mim em virtude do tempo em que são integrantes da Escola de Samba Portela, tendo em vista que todos têm mais de 50 anos na agremiação e mais de 70 anos de idade, ou seja, são considerados baluartes da Portela.

Organizei um cronograma para obter os dados junto aos sambistas no período de junho de 2012 a agosto de 2012, e para tal segui aos encontros, que foram marcados em eventos e lugares públicos, munida de instrumento eletrônico com capacidade de filmar, gravar e fotografar, e de bloco de anotações para auxiliar na sistematização das narrativas dos sambistas.

Então, como declara Benjamin (1985) acerca da narrativa,

a narrativa que durante tanto tempo floresceu num meio de artesão no campo, no mar e na cidade -, é ela própria, num certo sentido, uma forma artesanal de comunicação. Ela não está interessada em transmitir o "puro em si" da coisa narrada como informação ou um relatório. Ela mergulha a coisa na vida do narrador para em seguida retirá-la dele. Assim se imprime na narrativa a marca do narrador como a mão do oleiro na argila do vaso (p. 205). 


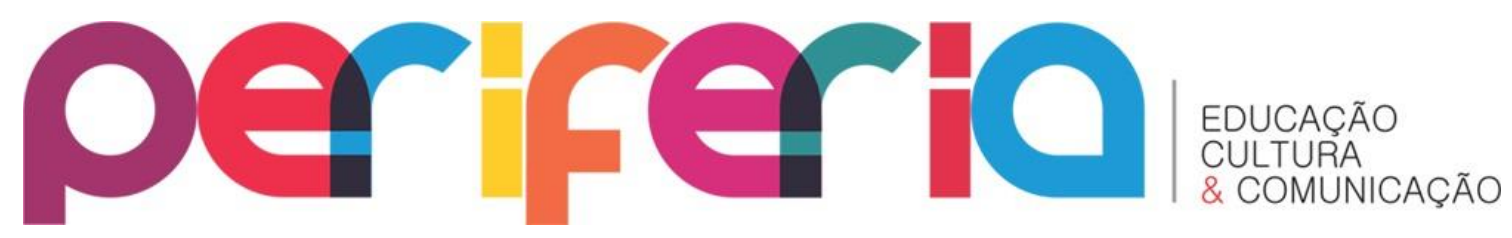

Neste contexto exposto por Benjamin, podemos declarar que as narrativas dos sambistas de Madureira e Oswaldo Cruz estabelecem, no ato de contar sobre sua vida e de seus amigos, uma relação artesanal ao atuar como um sábio que detém o conhecimento de toda uma vida e até mesmo da vida do outro.

\section{Dona Neném (Iolanda de Almeida Andrade)}

Certo dia de junho de 2012 encontrei Áurea Maria no mercado, próximo à minha casa, e ela me convidou para um encontro entre amigos que iria acontecer naquele dia em sua casa. Horas depois segui para a casa de Áurea Maria e, ao chegar lá, encontrei Dona Neném sentada com uma amiga nos fundos do quintal, bebendo uma cerveja. Aproveitei o momento para estabelecer uma conversa com ela, esposa do compositor Manaceia, e mãe de Áurea Maria (pastora da Velha Guarda da Portela).

A matriarca da família narrou que a casa onde ela vive até os dias de hoje foi comprada por sua mãe, Dona Ana, na década de 1930. As rodas de samba em seu quintal começaram com a mudança da família do bairro de Botafogo para o subúrbio de Oswaldo Cruz. Dona Ana, ao perceber a tristeza de seu filho Lincoln por não morar mais em uma área nobre, comprou-lhe um violão com parte do dinheiro recebido do pecúlio de seu marido falecido. Lincoln, que trabalhava na cidade, passou a se relacionar com compositores que se reuniam em frente ao Edifício Darke, na Cinelândia, e começou a escrever sambas.

Dona Ana, então viúva, se casou com um vizinho também viúvo que tinha o hábito de se reunir com amigos para tocar chorinho. Seu filho Lincoln começou a trazer seus amigos para o quintal da família, dentre eles os compositores Aniceto e Paulo da Portela. Nesses encontros, os compositores e músicos se reuniam para cantar e tocar. Enquanto isso, Dona Ana cuidava das iguarias para alimentar os amantes do chorinho e do samba que frequentavam seu quintal. Ela não permitia que eles saíssem dos encontros festivos sem experimentar suas iguarias.

Foi nesse universo, entre vizinhos, familiares e amigos de Lincoln, que Dona Neném conheceu o compositor Manaceia, irmão dos compositores Aniceto e Miginha, 


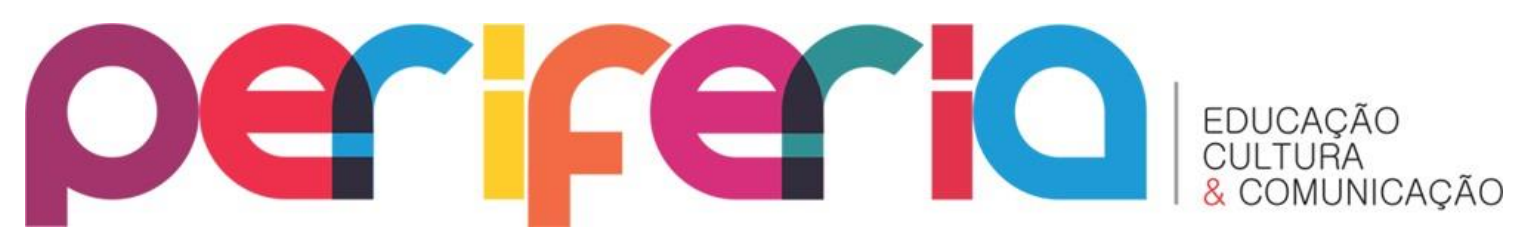

e se casaram. Desse casamento nasceram Heloísa e Áurea Maria. O casal ainda criou uma sobrinha de Dona Neném, Ana Maria.

Essa família de afrodescendentes, hoje com netos e bisnetos, reside no quintal de Dona Ana em Oswaldo Cruz. A casa de Dona Ana, na época da adolescência e vida adulta de suas filhas, passou a ser um a espécie de atelier da Escola de Samba Portela, pois as jovens se reuniam no quintal para elaborar fantasias para o desfile. Após o falecimento de Dona Ana, o casal Neném e Manaceia e suas filhas deram continuidade às atividades festivas no quintal e ao atelier improvisado para a roupa das meninas.

Dona Neném contou que, em certa ocasião, as meninas não tinham dinheiro para comprar tecido e a cauda de seu vestido de noiva foi utilizada para fazer a fantasia de Ana Maria e da Surica. Segundo Dona Neném, Surica se encarregava de procurar, entre os sambistas dos bairros de Madureira e Oswaldo Cruz, sobras de adereços para estilizar as fantasias para elas desfilarem na Portela.

Dona Neném narrou que os encontros com rodas de samba em seu quintal eram corriqueiros entre familiares e vizinhos. Era comum, sempre depois de um jogo de sueca, seu marido Manaceia começar a tocar cavaquinho e as crianças acompanharem cantando. Enquanto isso, a sopa de ervilha ou de legumes era providenciada.

Esses encontros geraram a preparação de composições e atraíram pessoas famosas do mundo do samba, como Paulinho da Viola, que foi levado ao quintal da família e se encantou com aquele encontro. Ela, Dona Neném, contou que certo dia Paulinho compareceu em sua casa à procura do seu marido, o compositor Manaceia, que estava na casa de amigos em Vila Isabel.

Dona Neném passou o endereço para Paulinho e ele seguiu para onde se encontrava o seu marido. Surpreendentemente, Paulinho chegou à casa dos amigos de Seu Manaceia e foi um alvoroço. Os donos da casa pediram aos vizinhos que emprestassem louças mais apresentáveis para servir ao cantor. O dono da casa, Seu Pará, chegou a chorar de emoção. 


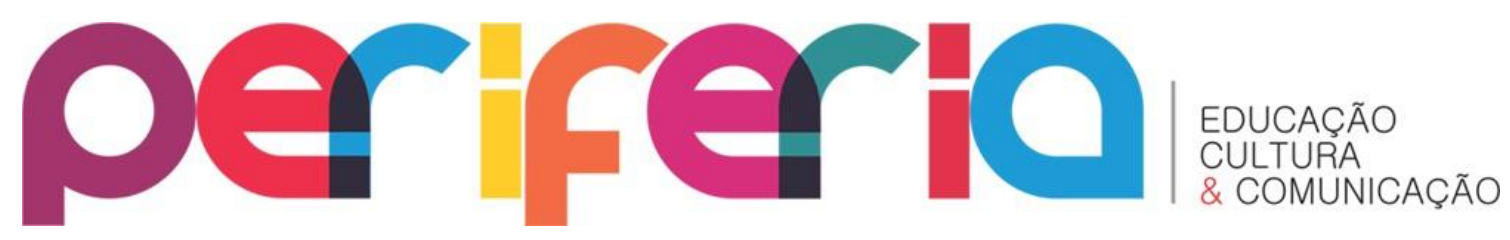

O motivo da visita de Paulinho da Viola ao compositor Manaceia foi propor a filmagem de um documentário em seu quintal e, de acordo com Dona Neném, seu Manaceia aceitou e então foram filmados os encontros de rodas de samba. Tal documentário recebeu a denominação Partido Alto, dirigido por Leon Hirszman e narrado por Paulinho da Viola, filmado em 1976, mas lançado somente em 1982. As filmagens, segundo Dona Neném, aconteceram no quintal de Manaceia, no bairro de Oswaldo Cruz, e no quintal do compositor Candeia, no bairro de Jacarepaguá.

Dona Neném finalizou que a presença de Paulinho da Viola junto ao grupo de sambistas de Oswaldo Cruz culminou na organização do grupo de show Velha Guarda da Portela, e Paulinho da Viola recebeu o título de padrinho da Velha Guarda.

\section{Zilmar Mendonça}

Ao encontrar Zilmar Mendonça, filha do ex-Presidente da Portela, Seu João Calça Curta, marcamos um encontro para o mês de julho de 2012, em seu apartamento, que fica em frente à quadra da Portela, em Madureira. No momento que cheguei ao encontro tive recepção muito calorosa, acompanhada de petiscos e uma agradável conversa.

Ela contou que a peixada em seu quintal, promovida por seu pai, no bairro de Oswaldo Cruz, ficou tão famosa na época que atraiu revistas e jornais (Fatos \& Fotos e O Globo). Contou também que Natal da Portela, figura lendária, nos dias da peixada passava em sua casa e de gozação dizia ao Seu João que "se faltar peixe, eu pego no meu alcário".

O alcário a que Natal da Portela se referia, de acordo com Zilmar, era o aquário que ele tinha em sua casa. Natal era conhecido por se atrapalhar com as palavras. Zilmar mencionou que personagens de outras escolas de samba, como Salgueiro e Império Serrano, também frequentavam a peixada de Seu João, embora a proposta fosse discutir o desfile da Portela. Zilmar Mendonça também contou que os encontros promovidos no quintal por seu pai enquanto era presidente da Portela, aconteciam 


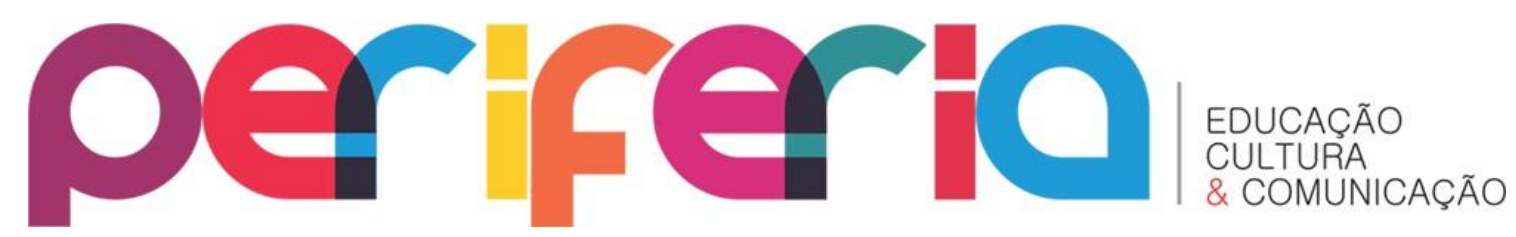

não só na quarta-feira de cinzas como no dia que antecedia o desfile. Ele promovia um feijão para um grupo seleto, a fim de discutir o desfile da Portela.

Nos dias de Momo, grupos de desfilantes, antes do desfile oficial da Portela, promoviam um bloco de sujo no bairro de Oswaldo Cruz. Os desfilantes passavam no quintal da família Mendonça e Dona Léa, esposa de João Calça Curta, já os esperava para servir-Ihes cachorro-quente e batida de limão.

Zilmar relatou que seu pai era muito namorador. Como esse encontro dos blocos de embalo da Portela acontecia na casa de sua mãe, uma namorada que seu pai tinha em Cascadura passou a promover lanches para receber os foliões da Portela. E, consequentemente, carregar seu João para o quintal dela para receber os foliões.

Segundo Zilmar, tais encontros promovidos por Seu João em seu quintal só terminaram com a morte de sua mãe, em 1978, e nessa última roda de samba ou pagode, como João Calça Curta denominava, foram consumidos $120 \mathrm{~kg}$ de peixes. Zilmar desabafa, ao final da entrevista, que, embora seu pai tenha sido uma pessoa que contribuiu significativamente para o universo do samba, especificamente para a Portela, às vezes ela é impedida de entrar na quadra por funcionários que desconhecem a contribuição de sua família para a história cultural e social da referida escola de samba e do bairro de Oswaldo Cruz. É importante ressaltar que Zilmar é uma mulher de seus 70 anos de idade e que as pessoas que a impedem de entrar sem identificação institucional (carteira de sócio benemérito) são pessoas contratadas pela agremiação para prestar serviço na portaria; logo, Zilmar não concebe o modelo de organização moderna da referida agremiação.

\section{Davi do Pandeiro (Davi de Araújo)}

A conversa com o músico, cantor e compositor Davi do Pandeiro, integrante da Velha Guarda Show da Portela, grupo da Velha Guarda da Portela que se apresenta em shows e participa de vocais em produções musicais, aconteceu no camarim do Cordão da Bola Preta, em agosto de 2012, pois já havíamos combinado um encontro no local em questão na festa de aniversário do compositor Monarco. Iniciamos nossa conversa 


\section{periferio}

após Seu Davi, aos seus 78 de idade, comer uma suculenta feijoada antes da apresentação.

Davi do Pandeiro iniciou a conversa contando que sua avó veio para o Brasil em um dos navios negreiros que comercializavam escravos e que seu pai nasceu em terras brasileiras. Os ancestrais de Davi, de acordo com ele, foram escravos em uma fazenda em Ubá, no Estado de Minas Gerais. Após a Abolição da Escravidão, saíram da fazenda e vieram para o Rio de Janeiro. Ao chegarem aqui, fixaram residência em Madureira e seu entorno.

Nas primeiras décadas do século XX, seu tio Juvenal se destacava por promover no seu quintal, em Madureira, jogos de dama, rodas de samba e chorinho. Esses encontros contavam com a presença de compositores como Donga, Pixinguinha e Paulo da Portela. Era comum a família, vizinhos e amigos promoverem um bloco do sujo no período do carnaval. O samba era versado pelos sambistas presentes e ritmado pelos músicos com flautas, clarinete e outros instrumentos.

A tia de Seu Davi e outras mulheres da família ou da vizinhança cuidavam da comida para nutrir os foliões e sambistas nos dias de Momo e nos dias de roda de samba. No bloco promovido por sua família, os homens se vestiam de mulher e as mulheres se vestiam de homem. Segundo Seu Davi,

\footnotetext{
nessa época as rodas de samba e os blocos não contavam com o surdo de marcação, porém o violão, reco-reco, cabaças, bandolim, matraca, castanhola e pratos de louças tocados com facas ou colheres faziam parte da bateria ou conjunto das rodas de samba (SEU DAVI).
}

O pai de Davi, de acordo com seu relato, tocava nas rodas de samba das casas das tias baianas no centro da cidade do Rio de Janeiro. As tias a quem Seu Davi se refere eram Tia Ciata, Tia Perpétua, Tia Amélia do Aragão, Tia Perciliana e Tia Mônica (consideradas as tias do samba, que acolhiam sambistas em suas casas). Ele, desde criança, frequentava a casa das tias baianas junto com seu pai e já era elogiado por elas pelos passos de samba que mesmo pequeno desempenhava. 


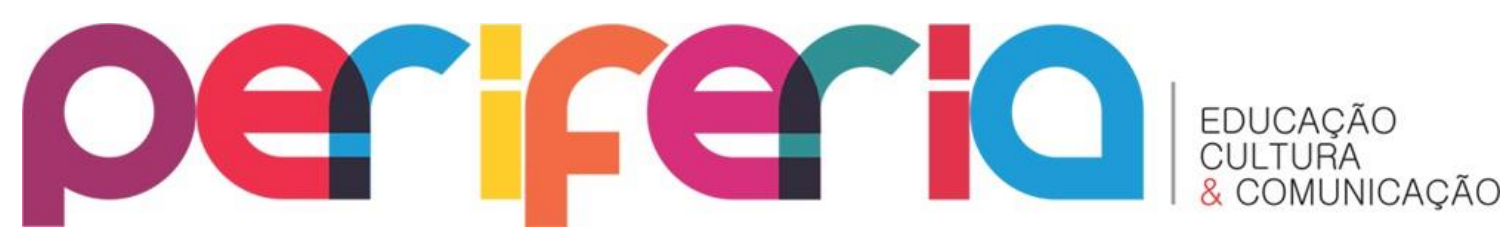

Davi do Pandeiro relatou que seu pai e sua mãe se separaram em 1943. Sua mãe o internou juntamente com seu irmão, pois não queria que eles se envolvessem com o samba, uma vez que ela não gostava da cultura. Ele foi para um colégio da cidade de Passa Quatro e seu irmão para o bairro de Quintino, na Escola XV. No internato, ele se unia aos colegas e fazia pandeiro da lata de goiabada. Inventava uns versos e durante o carnaval desfilava no bloco da instituição de camisola e com a cabeça raspada.

Certo dia, Davi veio visitar sua mãe e não voltou mais para o internato em Passa Quatro. Sua mãe solicitou sua transferência para a Escola XV em Quintino, espaço que abrigava filhos de mães viúvas, separadas e crianças abandonadas, onde estava internado seu irmão e lá permaneceu até 1949. Ao sair do internato e voltar para viver ao lado de sua mãe, ele pediu a uma vizinha que o levasse ao Bloco Paz e $\mathrm{Amor}^{2}$ de Bento Ribeiro para se divertir. Após essa visita ao bloco, ele começou a tocar pandeiro e passou a ser o primeiro pandeirista, desfilando à frente da bateria do Bloco.

A partir daí, começou a fazer de sua arte lazer e profissão, ao ministrar aulas de pandeiro e sair à frente da bateria. No período em questão, já à frente da bateria do Unidos da Capela ${ }^{3}$, começou a participar como músico no grupo do cantor e compositor Herivelto Martins, além de trabalhar nas Rádios Tupi e Mayrink Veiga como músico.

O pandeirista Davi comentou que, junto de Mestre André da Mocidade Independente de Padre Miguel, saiu à frente da bateria daquela escola de samba. 0 maior pontapé para sua carreira foi o lançamento do CD Tudo Azul, da Velha Guarda da Portela. O lançamento do CD, iniciativa da cantora Marisa Monte, que também o produziu, deu a ele a oportunidade de fazer viagens para fora do Brasil, participar de

\footnotetext{
${ }^{2}$ Havia no bairro de Bento Ribeiro duas escolas de samba, consideradas excelentes, que desfilavam com as grandes escolas: Lira do Amor (com sede na Rua Pacheco da Rocha) e Paz e Amor (com sede na Rua Tácito Esmeris).

${ }^{3}$ Fundada em 15 de janeiro de 1933, foi duas vezes campeã do Carnaval carioca, porém em ambas dividiu o título com outras escolas. Localizava-se à direita da Estação de Parada de Lucas (direção Duque de Caxias).
} 


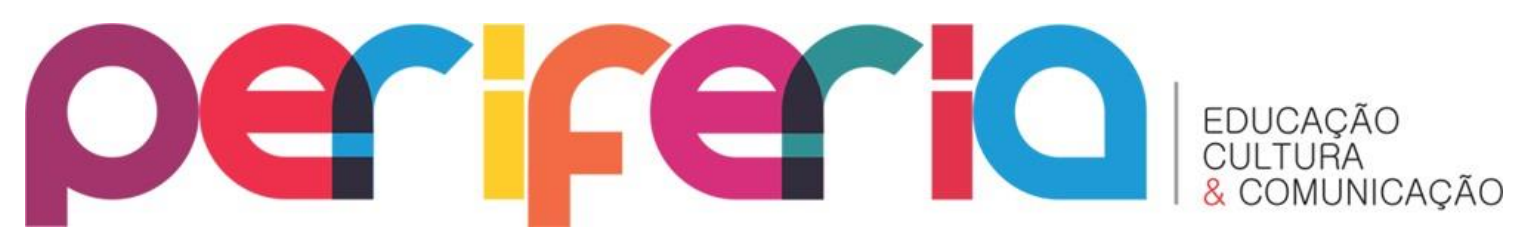

eventos da música brasileira no Theatro Municipal e shows em grandes casas de espetáculos no Rio de Janeiro e em outros estados brasileiros.

Em nossa conversa, Davi relatou que o negro, embora tenha vivido e ainda passe por muitas discriminações, tem o samba como trampolim para chegar a alguns espaços dentro da sociedade.

\section{Irani Belmiro da Cunha}

A narrativa dos eventos do quintal do falecido Argemiro do Patrocínio foi uma colaboração de Irani, amiga do compositor e irmã de Tia Surica. A conversa aconteceu no enterro dos ossos da festa de aniversário de uma amiga, realizado no quintal das irmãs em junho de 2012. Irani contou que Argemiro vivia em um quintal situado numa vila de casas em Oswaldo Cruz e às quartas-feiras, após o término da feira que acontecia no local, tinha início o ensaio do grupo Velha Guarda Show.

Esse espaço era frequentado por cantores e compositores de nome e os vizinhos nem se incomodavam com o batuque na roda de samba, em virtude da presença dos visitantes ilustres. Ela contou ainda que esses encontros no quintal de Argemiro se iniciaram quando um dia os compositores Monarco, Argemiro e Alberto Lonato, todos integrantes, na década de 1980, da Velha Guarda Show da Portela começaram a fazer um peixe às quartas-feiras. "Nesse dia eles promoviam uma roda de samba redondinha!", exclama Irani.

Nos encontros promovidos pelos sambistas não havia a figura feminina para cuidar das iguarias; logo eles chamaram Surica, a falecida Doca e Eunice ${ }^{4}$ para preparar os alimentos. O peixe às vezes era frito e outras, cozido, sempre acompanhado de bebidas quentes e cervejas. Algumas vezes eram servidos carne seca com abóbora, tripa lombeira e, para tira gosto, jiló e quiabo. No final, Argemiro exigia que as louças fossem lavadas. Segundo Irani, certa vez Zeca Pagodinho foi à casa de Argemiro com umas amigas, comeram e beberam e, quando Zeca se despediu, Argemiro disse: "Vai embora nada, manda estas donas lavarem as louças!".

\footnotetext{
${ }^{4}$ Essas são integrantes da Velha Guarda Show da Portela conhecidas como pastoras.
} 


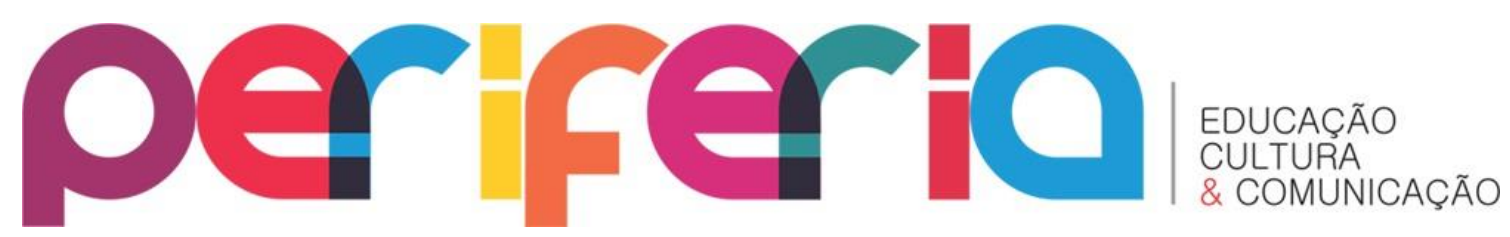

De acordo com Irani, a roda de samba do quintal do Argemiro ficou famosa. Certa vez, a Velha Guarda foi fazer um show fora de Madureira e alguns rapazes aproximaram-se do grupo e Argemiro os convidou para sua roda de samba. Após uma semana, esses rapazes faltaram ao trabalho, pegaram o trem para Oswaldo Cruz e, ao chegar ao bairro, saíram perguntando até chegar à casa do compositor. Eles se encantaram pelo ambiente e, a partir daquele encontro, um dos rapazes, Ceroli, se declarou portelense. De acordo com Ceroli, aquele espaço era contagiante pelas pessoas e pelo samba que ali se cantava e tocava. A partir daquela visita à roda de samba de Argemiro, esses rapazes passaram a faltar constantemente ao trabalho para comparecer ao encontro desse quintal.

Irani contou que Zeca Pagodinho tinha cadeira cativa às quartas-feiras na roda de samba. Outros participantes que também faziam parte de um grupo efetivo desse encontro eram Marquinhos Diniz, Cristina Buarque de Holanda e Paulão Sete Cordas. Certa vez Martinho da Vila prestigiou a roda de samba no quintal de Argemiro.

Conforme Irani,

\begin{abstract}
Argemiro era uma pessoa muito divertida e fazia caretas e graças com a falta de dentes que tinha. Toda vez que perguntavam a ele porque não colocava uma dentadura, ele dizia: 'a Beth Carvalho diz que é meu charme a falta de dentes!' (IRANI).
\end{abstract}

No momento, ela também se lembrou do samba de autoria de Argemiro que Beth Carvalho gravou e canta um pedaço da composição: “A chuva cai lá fora/Você vai se molhar/vai se molhar.../Até a própria natureza/Tá pedindo pra você ficar". Irani comentou ainda que, quando acabava a roda no quintal de Argemiro, todos seguiam para o botequim da esquina da casa dele e lá tomavam mais algumas cervejas. Irani exclamou, ao final de nossa conversa:

esses encontros só acabaram depois que ele foi morar com a Nina e ela o levou para viver no quintal de sua família em São João de Meriti! Mas, uma vez por outra, ele recebia os amigos na nova residência com o mesmo fervor que acontecia em Oswaldo Cruz tempos memoráveis, tempo bom que não volta mais! (IRANI).

\title{
Surica (Iranette Ferreira Barcellos)
}




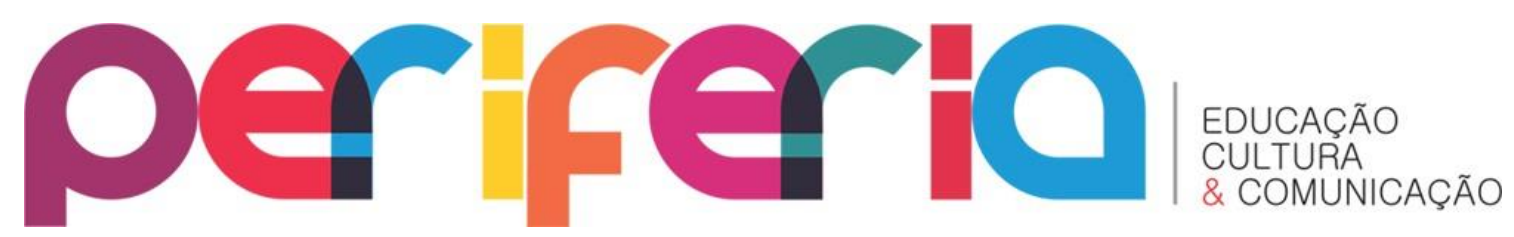

O encontro com Surica aconteceu no mesmo dia em que conversei com Irani, sua irmã, em junho de 2012. No mundo do samba, Surica é conhecida como Tia Surica; é famosa por promover feijoadas em eventos na cidade do Rio de Janeiro. Iniciamos nossa conversa com Surica narrando que desde os quatro anos de idade desfila pela Portela. Sua mãe a carregava encaixada no quadril para o desfile. Surica contou que sua mãe era oriunda do morro da Mangueira e seu pai, e codinome Pio, era integrante da Portela. Pio, morador de Madureira, teve 18 filhos com sua mãe, 16 filhos com a mulher com quem era casado e mais 16 filhos com outra mulher. Ela, entretanto, foi criada por sua avó e seu avô na Rua Júlio Fragoso, em Madureira.

De acordo com sua narrativa, ela foi muito discriminada quando adolescente. Os pais de outras garotas diziam para as filhas não andarem com ela por causa do samba: "O samba é reconhecido hoje como cultura e os sambistas têm valor. Antigamente eram discriminados. Hoje me aplaudem, mas já fui discriminada!".

Segundo Surica, em sua casa não aconteciam rodas de samba, mas ela fugia de casa para ir ao quintal de Dona Esther, frequentar os bailes e rodas de samba. Esse quintal era muito grande e contava com sambistas locais e de outros bairros. Surica também frequentava as rodas de samba do quintal do falecido compositor Manaceia, esposo de Dona Neném. Surica contou também que as rodas de samba em seu quintal começaram em seu aniversário de 50 anos, quando ela convidou muitas pessoas e dentre elas foram produtores de televisão, sambistas, cantores e outros personagens do mundo do samba.

A partir daquele evento, Tetéu e Manoel Alves, da Rede Globo de Televisão, produtores de revistas de carnaval e samba, começaram a fazer algumas matérias de samba no quintal onde ela mora. Eles contribuíam com produtos alimentícios para que fosse feita a comida e compravam a cerveja. Outras emissoras de televisão, como o SBT e a CNT, também fizeram algumas reportagens com teor de carnaval e samba. Algumas audições de CDs aconteceram no quintal da vila em que mora, como os de Marquinhos de Oswaldo Cruz, Ernesto Pires e o Tudo Azul, da Velha Guarda da Portela, produzido por Marisa Monte. 


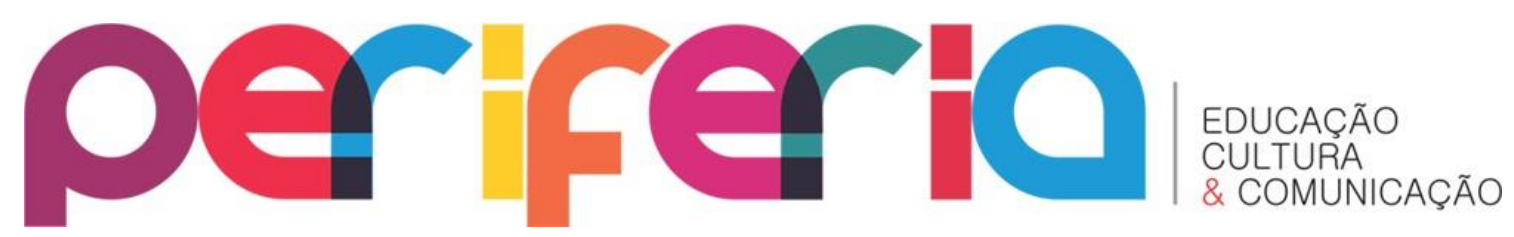

Esses eventos foram tomando vulto para amigos do samba e moradores da vila, que há 10 anos, no dia 1으 de janeiro, se encontram no quintal para comer, beber, ouvir samba, falar de carnaval e compartilhar as iguarias que os participantes levam. Além da comemoração do primeiro dia do ano, o dia da apuração dos desfiles também reúne um grupo grande de sambistas para assistir na TV à divulgação das notas dadas pelos jurados. Nesse dia, todos os participantes levam cervejas e um quilo de carne, asa ou linguiça para ser feito o churrasco. "Eu gosto de receber e promover essas festas. Eu quero manter a chama do samba acessa!", exclama Surica.

Ao conversarmos sobre os bairros de Madureira e Oswaldo Cruz, retomamos as histórias do passado e Surica relatou que os compositores muitas vezes mal assinavam o nome. É o caso, por exemplo, de Miginha, irmão de Manaceia, que não sabia ler, mas era compositor. Ela exclama: "A inspiração dessas pessoas vinha da alma, era a mão de Deus que estava sobre a cabeça delas!".

Ela expôs que sua relação com a família de Manaceia sempre foi muito intensa, e lembrou que já frequentava a casa da família desde época em que Dona Ana, sogra de Manaceia, e a mãe de Dona Neném eram vivas. Na época do carnaval, a casa de Dona Neném virava um ateliê. Como ela e a Ana (filha de dona Neném) ficavam loucas para desfilar na Portela, mas não tinham dinheiro, Dona Neném confeccionava a fantasia de baianinhas delas com o seu vestido de noiva.

Sua participação na Portela e com demais moradores se estreitava por causa do desfile de carnaval e das rodas de samba que aconteciam em Madureira e Oswaldo Cruz. Surica contou que esse envolvimento com o universo do samba, especificamente com a Portela, levou-a a ser componente de alas, a fazer parte do coro do desfile da escola de samba e que até samba puxou na avenida.

Contou que, em 1966, foi convidada por Natal da Portela para defender o samba de Paulinho da Viola na avenida. O enredo foi Memórias de um Sargento de Milícias e, no momento do convite, ela ficou com as pernas bambas de tanta felicidade. Naquela época as escolas de samba ficavam na avenida mais de duas horas, não tinha cronometragem. "E haja gogó. No final do desfile a voz estava boa, mas os 


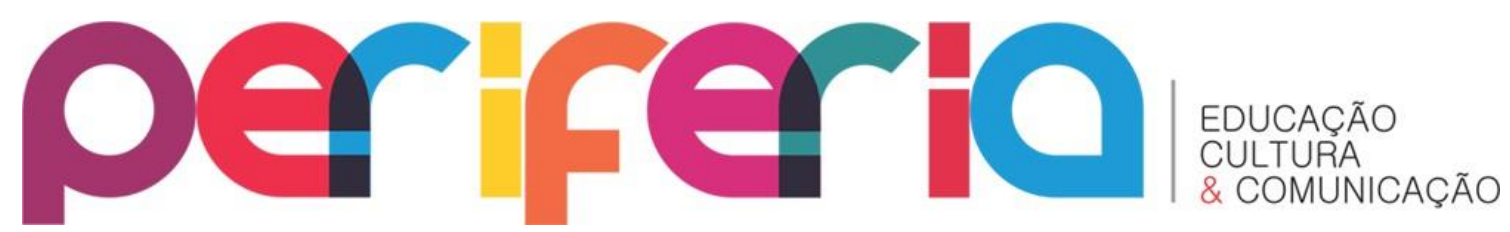

pés estavam todos machucados, de tanto tempo andando!". Nesse ano, narrou Surica, a Portela foi campeã e o samba-enredo foi o único da carreira de compositor de Paulinho da Viola na história da Portela.

O envolvimento de Surica com a Velha Guarda Show da Portela começou quando, em 1980, o compositor Manaceia a chamou e pediu para ela cantar sambas de terreiro da Portela. Ao terminar de cantar, Manaceia disse que ela era a mais nova integrante do grupo: "Era um teste e eu nem sabia!".

Ao retomarmos o assunto do seu quintal, Surica comentou que muitos artistas e políticos passaram por lá e que inclusive um dos aniversários de Marisa Monte foi festejado em seu quintal. O prato foi galinha com macarrão, acompanhado de muita cerveja. Nesse dia, estiveram presentes Alcione (a Marrom), Miúcha, Carlinhos Brown e Beth Carvalho, que sempre está presente nos festejos do quintal de Surica.

Além desses participantes ilustres, ela apresentou uma lista de pessoas que já participaram das rodas de samba em seu quintal: os artistas Cristina Buarque de Holanda, Marquinho Satã, Martinho da Vila, Adriana Bombom, Dudu Nobre, Zeca Pagodinho, Neguinho da Beija Flor, Beth Mendes e Adriana Lessa; os carnavalescos Silvio Cunha, Alexandre Louzada, Caê Rodrigues, Milton Cunha e Amarildo; e os políticos Eliomar Coelho (vereador), o ex-ministro da Cultura Francisco Weffort e o atual prefeito, Eduardo Paes.

Seja em seu aniversário e de amigos ou em festejos sem motivo aparente, ela gosta é de receber amigos em seu cafofo e cantar os sambas memoráveis. Ela conta que seu envolvimento com o samba tem Ihe rendido visibilidade no cenário carioca, tanto que ela tem um espaço para receber seus convidados e mostrar seus dotes culinários e de suas meninas, como ela se refere à irmã Irani, a primas e amigas que fazem a feijoada, que acontece no último sábado de cada mês do Teatro Rival.

Os dotes culinários de Surica a levaram a ministrar eventos de cervejaria em um bar da Lapa, em encontros políticos como os do prefeito Eduardo Paes e aniversários de amigos. Também esteve presente no lançamento do bloco em homenagem a Paulinho da Viola, o Timoneiro da Viola, que aconteceu no início de 2012 em seu 


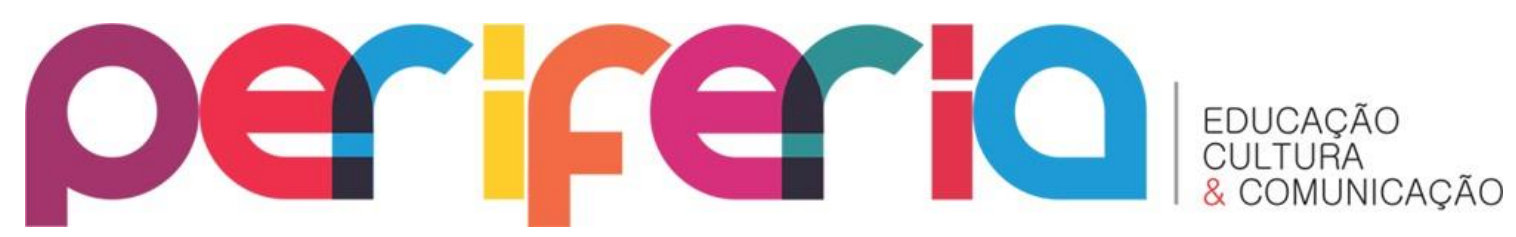

quintal; o prefeito também esteve presente nele. Sua casa é conhecida como "Cafofo da Surica", alcunha proferida por seu amigo Ceroli, e na porta da entrada tem uma placa a reproduz.

Ela exclamou, no final da conversa: "Acho que vou registrar o nome Cafofo da Surica!".

E assim as narrativas dos sambistas de Madureira e Oswaldo Cruz revelam, pelas memórias transcritas, as contribuições culturais dos grupos étnicos existentes na cidade carioca.

\section{CONSIDERAÇÕES FINAIS}

A partir das contribuições literárias e das narrativas dos sambistas de Madureira e Oswaldo Cruz abordadas neste artigo, podemos observar a história dos afrodescendentes no cenário carioca no que se refere à cultura do samba e nas relações sociais estabelecidas entre os grupos étnicos. Essa população, embora à margem da sociedade carioca, promoveu e ainda promove um modelo de entretenimento nos bairros suburbanos, especificamente Madureira e Oswaldo Cruz, e mostra processos de socialização e civilidade no trato com seus semelhantes.

As transcrições das narrativas dos sambistas revelam o quanto esses afrocariocas contribuíram e ainda contribuem para a manutenção de uma cultura étnica que se manifesta nas festas, nas comidas e nas rodas de samba promovidas em seus quintais e de amigos.

Observamos também, pelas narrativas dos sambistas, o quanto as rodas de samba consolidaram as práticas de construções coletivas. Além disso, esses encontros foram elos entre os grupos de sambistas, de suas comunidades e até mesmo de outras, o que torna tais práticas uma lição de civilidade e uma rica demonstração de convivência, bem como mostra como se dão as trocas de conhecimento no contexto das aprendizagens culturais.

No entanto, ao descrevermos, nesta investigação, como o negro foi tratado discriminadamente e contarmos suas histórias de contribuições nas artes - na música 


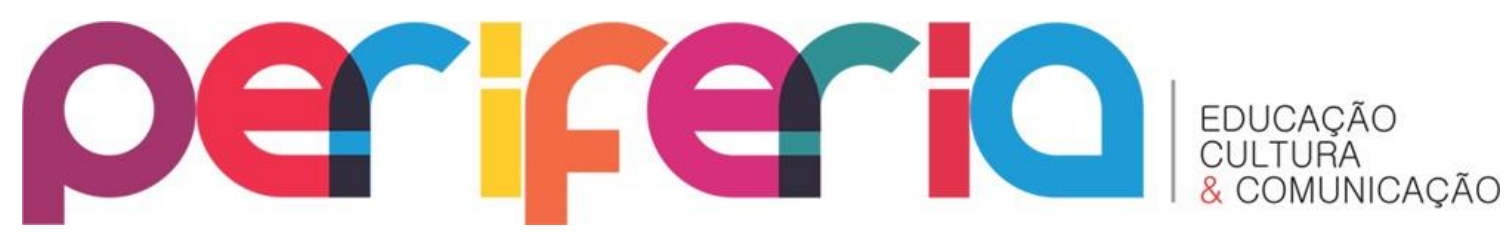

dentre outros aspectos -, estamos tratando o negro como sujeito imprescindível no processo de constituição cultural da cidade do Rio de Janeiro. Isso significa a valorização do seu legado na cultura afro-carioca, à qual fornecerá subsídios para que possamos discutir e programar em nossas classes do Ensino Fundamental, Ensino Médio e Superior o princípio estabelecido pela Lei no $10.639 / 03$, que versa sobre o ensino da história e da cultura afro-brasileiras e africanas e ressalta a importância da cultura negra na formação da sociedade brasileira.

Nesse sentido, consideramos as narrativas dos sambistas apresentadas neste artigo de suma importância para a transmissão de um aspecto pouco abordado em literatura e pouco difundido nos espaços acadêmicos.

\section{REFERÊNCIAS}

ARAÚJO, Hiran. Carnaval - seis milênios de história. Rio de Janeiro: Gryphus, 2000.

BENJAMIN, Walter. Magia e técnica arte e política. Ensaios sobre literaturas e história da cultura. Trad. Sérgio Paulo Rouanet. São Paulo: Brasiliense, 1985.

RIBEIRO, Elisa Antônia. A perspectiva da entrevista na investigação qualitativa. Evidência: olhares e pesquisa em saberes educacionais, Araxá, no 4, p.129-148, maio $2008 . \quad$ Disponível em: www.uniaraxa.edu.br/ojs/index.php/evidencia/article/download/.../310. Acesso em set. 2014.

ROCHA, Oswaldo Porto. A era das demolições. Rio de Janeiro: Prefeitura da Cidade do Rio de Janeiro/SMC, 1995. Coleção Biblioteca Carioca.

THEODORO Helena et alii. Dossiê das matrizes do samba do Rio de Janeiro. Rio de Janeiro: IPHAN, 2005.

VARGENS, João Baptista; MONTE, Carlos. A Velha Guarda da Portela. Rio de Janeiro: Manati, 2001. 